\title{
Direct visualization of remyelination in multiple sclerosis using T2-weighted high-field MRI
}

\footnotetext{
Figure Demyelinated (block arrow) and partially remyelinated (red arrow = demyelinated; blue arrows = remyelinated) lesions in postmortem multiple sclerosis brain
}
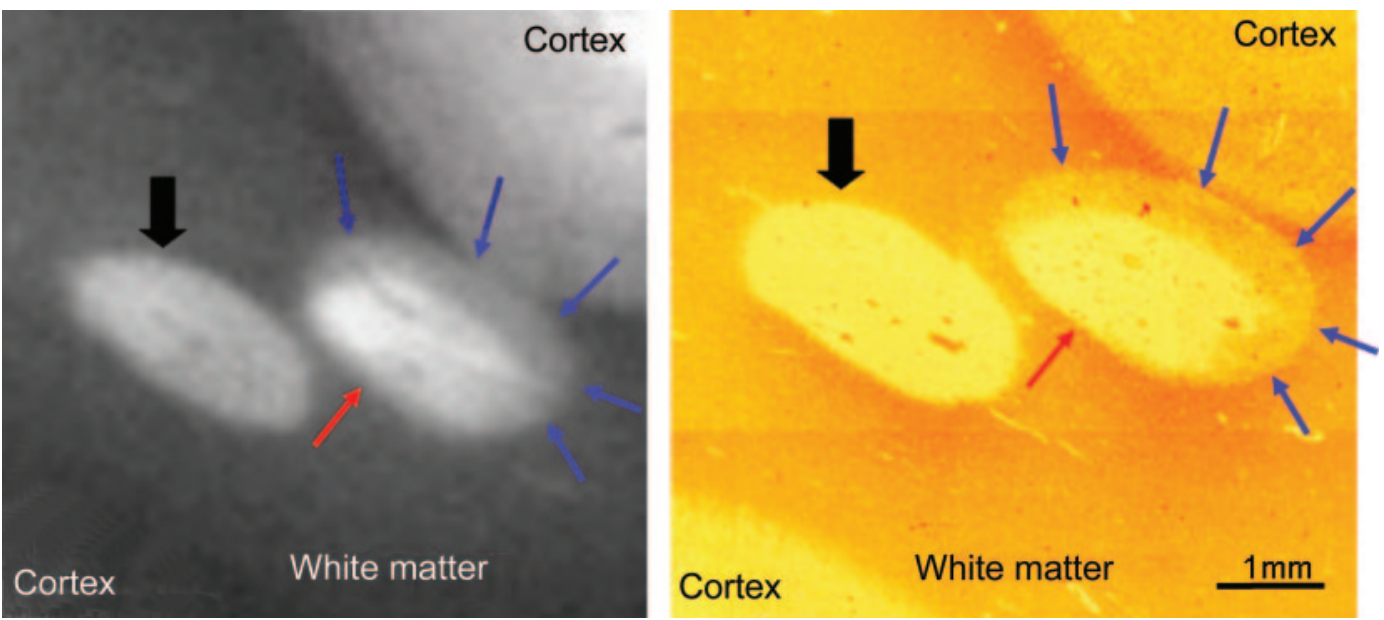

Spin-echo MRI (relaxation time $=3,000 \mathrm{msec}$, echo time $=60 \mathrm{msec}$, field of view $=30 \times 30 \mathrm{~mm}^{2}$, matrix size $256 \times 256$ [ 117 $\mu \mathrm{m}^{2}$ in-plane resolution], 16 averages). The corresponding histologic section was immunostained for myelin basic protein.

In multiple sclerosis (MS), remyelination may restore conduction and prevent axonal degeneration. ${ }^{1}$ Ability to monitor remyelination in MS in vivo would benefit natural history studies and clinical trials of novel drugs. ${ }^{2}$ High-field MRI ( $\geq 3 \mathrm{~T}$ ) is a promising tool to detect remyelination. We scanned a block of postmortem MS brain at 9.4 T. Histology revealed two areas of demyelination, and one showing remyelination. These findings corresponded to distinct changes visible on the T2-weighted MRI (figure). As human high-field MRI systems become increasingly widespread, remyelination in patients with MS may become detectable on T2-weighted scans.

Klaus Schmierer, PhD, Harold G. Parkes, PhD, Po-Wah So, PhD, London, UK

Supported by the Wellcome Trust (grant 075941) and the Multiple Sclerosis Society of Great Britain \& Northern Ireland. Disclosure: The authors report no disclosures.

Address correspondence and reprint requests to Dr. Klaus Schmierer, Institute of Neurology, University College London, Department of Neuroinflammation, NMR Research Unit, Queen Square,London WC1N3BG, UK; k.schmierer@ion.ucl.ac.uk

1. Rodriguez M. Effectors of demyelination and remyelination in the CNS: implications for multiple sclerosis. Brain Pathol 2007;17:219-229.

2. Zhao C, Zawadzka M, Roulois AJA, Bruce CC, Franklin RJM. Promoting remyelination in multiple sclerosis by endogenous adult neural stem/precursor cells: Defining cellular targets. J Neurol Sci 2008;265:12-16. 


\section{Neurology}

\section{Direct visualization of remyelination in multiple sclerosis using T2-weighted high-field MRI}

Klaus Schmierer, Harold G. Parkes and Po-Wah So

Neurology 2009;72;472

DOI 10.1212/01.wnl.0000341878.80395.39

This information is current as of February 2, 2009

\section{Updated Information \&} Services

References

Subspecialty Collections

Permissions \& Licensing

Reprints including high resolution figures, can be found at: http://n.neurology.org/content/72/5/472.full

This article cites 2 articles, 0 of which you can access for free at: http://n.neurology.org/content/72/5/472.full\#ref-list-1

This article, along with others on similar topics, appears in the following collection(s):

All Demyelinating disease (CNS)

http://n.neurology.org/cgi/collection/all_demyelinating_disease_cns MRI

http://n.neurology.org/cgi/collection/mri

Multiple sclerosis

http://n.neurology.org/cgi/collection/multiple_sclerosis

Information about reproducing this article in parts (figures,tables) or in its entirety can be found online at:

http://www.neurology.org/about/about_the_journal\#permissions

Information about ordering reprints can be found online:

http://n.neurology.org/subscribers/advertise

Neurology ${ }^{\circledR}$ is the official journal of the American Academy of Neurology. Published continuously since 1951, it is now a weekly with 48 issues per year. Copyright . All rights reserved. Print ISSN: 0028-3878. Online ISSN: 1526-632X.

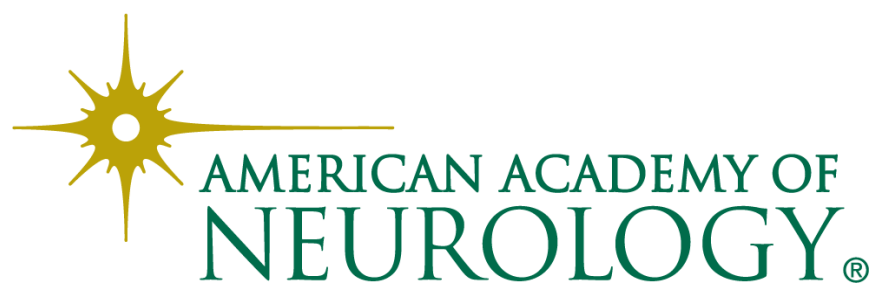

